\title{
Noise-Induced Hearing Loss and Associated Genes
}

\author{
Gozde Oztan (Corresponding author) \\ Istanbul University, Department of Medicine, Department of Medical Biology \\ Istanbul, Turkey \\ E-mail: gozdeoztan@yahoo.com \\ Halim Issever \\ Istanbul University, Department of Medicine, Department of Public Health \\ Istanbul, Turkey \\ E-mail: halimissever@gmail.com
}

\begin{abstract}
Noise-induced hearing loss (NIHL) is the most common occupational disease in the world and is the second most important cause of sensorineural hearing loss. Genetic and environmental factors are effective in the emergence of the disease. The World Health Organization (WHO) and the National Institute for Occupational Safety and Health (NIOSH) have classified NIHL as a research priority group. In this review, it is aimed to reveal the role of genetic variations and gene expression changes associated with susceptibility to noise-induced hearing loss in susceptibility to noise exposure. It can be said that genetic variations in heat shock protein 70 (Hsp70), 8-oxoG DNA glycosylase 1 (OGG1), Glutathione S-transferase M1 (GSTM1), catalase (CAT), Cadherin-23 (CDH23), Potassium Voltage Gated Channel Subfamily E Regulatory Subunit 1 (KCNE1) genes are associated with the risk of NIHL. Oxidative stress genes, inner ear potassium recycle pathway genes and monogenic hearing loss genes are accepted as candidate genes as genetic factors in NIHL. Individuals exposed to noise and at higher risk of developing NIHL are exposed to other environmental factors that interact with possible NIHL genes. More frequent use of high-throughput genotyping methods will allow the detection of multiple SNPs in a single sequence, making it possible to identify new NIHL susceptibility genes. This includes identifying individuals at high risk of developing NIHL and providing better hearing protection for susceptible individuals for noise-induced hearing loss. Thus, it could allow the development of genetic tests to help personalize treatment.
\end{abstract}

Keywords: GBİK, occupational disease, genetic variations

Special Issue of Health Sciences

DOI: $10.7176 /$ JSTR/7-08-07

\section{Gürültüye bağlı işitme kaybı ve ilişkili olduğu genler}

Özet

Gürültüye bağlı işitme kaybı (GBİK), dünyadaki en yaygın meslek hastalığı grubunda yer almakta olup sensörinöral işitme kaybının ikinci önemli sebebidir. Genetik ve çevresel faktörler hastalığın ortaya çıkmasında etkilidir. Dünya Sağlı Örgütü (WHO) ve Ulusal Mesleki Güvenlik ve Sağlık Enstitüsü (NIOSH), GBİK'yı araştırma önceliği verilen grup olarak sınıflandırmıştır. Bu derlemede, gürültüye bağlı işitme kaybına yatkınlıkla ilişkili genetik varyasyonların ve gen ekspresyon değişikliklerinin gürültü maruziyetine duyarllılktaki rollerinin ortaya konulması amaçlanmıştır. Isı şoku proteini 70 (Hsp70), 8-oxoG DNA glikosilaz 1 (OGG1), Glutatyon S-transferaz M1 (GSTM1), katalaz (CAT), Cadherin-23 (CDH23), Potasyum Voltaj Kapılı Kanal Alt Ailesi E Düzenleyici Alt Birim 1(KCNE1) genlerindeki genetik varyasyonların GBİK riski ile ilişkili olduğu söylenebilir. GBİK'da genetik faktör olarak oksidatif stres genleri, iç kulak potasyum geri dönüşüm yolağı genleri ve monogenik işitme 
kaybı genleri, aday genler olarak kabul edilmektedir. Gürültüye maruz kalan ve GBİK geliştirme riski daha yüksek olan bireyler, olası GBİK genleriyle etkileşime giren diğer çevresel faktörlere maruz kalırlar. Yüksek verimli genotipleme yöntemlerinin daha sık kullanımı, tek bir dizide çok sayıda SNP'nin saptanmasına olanak tanıyarak yeni GBİK duyarlılık genlerinin tanımlanmasını mümkün hale getirecektir. Bu durum, GBİK geliştirme riski yüksek olan bireylerin tespitini ve gürültüye bağlı işitme kaybı açısından duyarlı bireylerin daha iyi işitme korumasının sağlanmasını kapsamaktadır. Böylece, tedavinin kişiselleştirilmesine yardımcı olacak genetik testlerin geliştirilmesine olanak sağlayabilir.

Anahtar kelimeler: NIHL, meslek hastalığı, genetik varyasyonlar

\section{Giriş}

Gürültü, özellikle işitme kaybına sebep olması açısından sağlı̆̆a zararlı olabilecek en önemli fiziksel etkenlerdendir [16]. Mesleksel olarak gürültü en sık görülen tehlikedir ve bu gürültü biçimine atfedilen engelliliğe göre ayarlanmış yaşam yılı oranı, 1990'dan (61.11/100 bin) 2017'ye (78.21/100 bin) kadar dünya çapında istikrarlı bir şekilde artmıştır [35]. Gürültüye bağlı işitme kaybı (GBİK), yüksek frekanslara (3-6 kHz arasında) kronik maruziyetle başlayan ve ağırlıklı olarak endüstriyel işçiler arasında görülen birincil meslek hastalığı olan sensörinöral bir işitme kaybıdır [16]. GBİK, çevresel faktörler ve duyarlılık genleri arasındaki etkileşimin neden olduğu karmaşık bir hastalıktır [10]. Gürültüye bağlı işitme kaybının gelişimi esas olarak maruz kalma süresinden ve koklear epitel hasarına neden olan gürültünün yoğunluğundan ve sıklığından kaynaklanmaktadır. Endüstriyel işçiler işyerinde aşırı gürültüye [8h $85 \mathrm{~dB}(\mathrm{~A})$ ] maruz kaldıklarında, koklea çok fazla enerji tüketir ve ardından çok sayıda serbest radikal açığa çıkar [31]. Antioksidan sistem bu serbest radikalleri nötralize edemediğinden koklear duyu epiteli hasar görür [3]. Sonuç olarak, süperoksit dismutaz, glutatyon Stransferaz ve katalaz gibi reaktif oksijen türlerinin düzenlenmesinde yer alan genler, kokleanın gürültüye bağlı işitme kaybına karşı hassasiyetini etkileyebilir [26].

GBİK, en yaygın mesleki koşullardan biri olup geniş bir endüstri yelpazesinde ortaya çıkmaktadır. Mesleki GBİK, zamanla kademeli olarak gelişir ve sürekli veya aralıklı gürültüye maruz kalmanın bir fonksiyonudur. Mesleki GBİK'nın temel özelliklerine baktığımızda, her zaman sensörinöraldir, öncelikle iç kulaktaki koklear tüy hücrelerini etkiler. Gürültü maruziyetlerinin çoğu her iki kulağı da simetrik olarak etkilediğinden tipik olarak iki taraflıdır. İlk işareti 3000, 4000 veya 6000 Hz'lik yüksek frekanslarda odyogramda $8000 \mathrm{~Hz}$ 'de iyileşme ile "çentiklenme"dir. Bu çentik tipik olarak bu frekanslardan birinde gelişir ve sürekli gürültüye maruz kalma ile bitişik frekansları etkiler. Gürültüye maruz kalma tek başına genellikle yüksek frekanslarda $75 \mathrm{~dB}$ 'den fazla ve düşük frekanslarda 40 dB'den fazla bir kayıp üretmez [27].

Son yıllarda, insanlara yönelik GBİK için duyarlılık genlerini belirlemeye çalışan ilişkilendirme çalışmalarında büyük bir artış olmuştur. Aday gen yaklaşımına dayalı olarak oksidatif stres genleri, iç kulak potasyum geri dönüşüm yolu genleri ve monogenik işitme kaybı genlerinin yanı sıra diğer genlerden oluşan bir grup çalışma yapılmıştır. Şimdiye kadar, potasyum iyon kanalları (KCNQ4 ve KCNE1), katalaz (CAT), protocadherin 15 (PCDH15), miyozin 14 (MYH14) ve 1s1 şoku proteini (HSP70) kodlayan genlerde umut verici sonuçlar elde edilmiştir [28].

Mesleki gürültü kaynaklı işitme kaybı (MGKİK), uzun süreli ve sürekli olarak aşırı gürültüye maruz kalma sonrasında işitsel işlev bozuklukları ile karakterize, yaygın bir meslek hastalığıdır. Gürültüye maruz kalan işçilerde MGKİK prevalansı \%7 ila \%21 arasında değiştiği belirlenmiştir. MikroRNA'lar (miR), bölünme veya translasyon represyonu için mRNA'ları hedefleyerek gen ekspresyonunun modüle edilmesinde önemli roller oynayan, kısa, tek sarmallı, kodlamayan bir RNA ailesidir. Ding ve arkadaşları, MGKİK denekleri ve kontroller arasındaki miR'ların plazma seviyesini karşılaştırmış ve MGKİK deneklerinde yukarı regüle edilen (miR-16-5p, miR-24-3p, miR-185-5p ve miR-451a) ve aşağı regüle edilen (miR-24, miR-185-5p ve miR-451a) miRNA'lar tanımlanmıştır. MGKİK erkek işçiler ve kontrol gruplarında serum miR ekspresyon profillerini karşılaştırmayı amaçlamışlardır. MGKIKK deneklerinde serum miR-1229-5p'nin önemli ölçüde yükseldiğini göstermişlerdir. Artan miR1229-5p, MAPK1 sinyalini baskılayarak MGKİK patogenezine katılabileceği söylenebilir [20].

Kronik gürültüye maruz kalma, endüstriyel çağın ve mekanize savaşın bir yan etkisidir ve GBİK, duyusal bir hasar olarak yalnızca yaşa bağlı işitme bozukluğundan (YBİB) sonra ikinci sıradadır. Tinnitus duyarlılığının altında yatan genler ve genetik yolaklar tanımlanmamıştır. Her iki bozukluğun da tedavisi veya kesin tedavisi yoktur. NIHL sıklıkla tinnitus ile komorbid olmasına rağmen, farklı patofizyolojik yapıları olduğu görülmektedir. Her iki bozukluğa da neden olan hasarlar, yüksek eşikli koklear sinir liflerinde birincil nöral dejenerasyonla birlikte kokleadan kaynaklanıyor gibi görünmektedir [11].

53 | P a g e

www.iiste.org 
GBİK, geri döndürülemez olarak kabul edilir. Aşırı gürültü, gen ifadesinde değişikliklere neden olabilir. Diferansiyel gen ekspresyonu, tüm doku ve organların gelişimi, farklılaşması, yenilenmesi ve plastisitesi dahil olmak üzere biyolojik süreçler için itici güç sağlar. Akustik aşırı uyarılma ile aktive edilen spesifik genlerin maruz kalma sıklığı, seviyesi, süresi ve maruz kaldıktan sonraki iyileşme süresi ile değişmesi muhtemeldir. Çalışmalar, Reg3b'nin motor nöronların gelişiminde ve yenilenmesinde önemli bir rolü olduğunu göstermiştir. Reg3b, hasarlı motor ve duyu nöronlarından salınır ve prorejeneratif bir işleve sahiptir. Reg3b'nin güçlü yukarı regülasyonu, koklear patogenezinde önemli bir işlevi olabileceğini düşündürmektedir. Lcn2 ve Serpina3n, çeşitli bozukluklarda iltihaplanma ile ilişkili akut faz proteinleridir; Lcn2, bağışıklık tepkilerinin düzenlenmesi, hücre büyümesi ve farklılaşması, demir taşınması ve prostaglandin sentezi gibi çeşitli işlevlere sahip bir taşıyıcıdır. Çalışma sonuçları, Lcn2'nin alerjen duyarlılığı ve hava yolu güçlükleri nedeniyle akciğer dokularında yukarı regüle edildiğini ve alerjik hava yolu hastalığında koruyucu işlevleri olduğunu ortaya koymuştur. Serpina3n, en büyük proteaz inhibitörleri ailesi olan multigen serpin ailesinin bir üyesidir ve apoptoz gibi çeşitli fizyolojik süreçlerde yer alır. Salgılanan Serpina3n, sitotoksik CD8 T hücresi (CTL) tarafindan indüklenen hedef hücre ölümünde yer alan granzim B aktivitesini ve granzim B aracılı öldürmeyi inhibe edebilir. Nob1 geni genomun yaklaşı 13 kb'sini kapsar ve bir N-terminal PIN domaininden ve bir C-terminal çinko şerit domaininden oluşur. Çalışmalar, Nob1'in stres kaynaklı apoptozda veya gürültü travmasına karşı koruyucu mekanizmalarda önemli bir rolü olacağını göstermektedir. Nob1'in koklear hücrelerdeki işlevi ve mekanizması henüz net değildir [22].

\section{Gürültüye bağlı işitme kaybında genlerin rolü}

\subsection{Oksidatif stres genleri}

Kokleada gürültüye bağlı reaktif oksijen türlerinin (ROS) üretimi iyi ayırt edilmiştir. Hem mitokondriyal disfonksiyon hem de ROS üretimi, mitokondriyal genler ve endojen antioksidan savunma ile ilişkili genler, aday genlerin GBİK ile ilişkilendirilmesini mümkün kılan nörodejeneratif koşullara dahildirler. Kokleada farklı antioksidan enzimler aktiftir ve bunlardan bazıları glutatyon (GSH) metabolizmasında yer alır (glutatyon S-transferaz, GST; glutatyon peroksidaz, GPX1; glutatyon redüktaz, GSR). Glutatyon-S-transferaz (GST) enzimleri, GSH'nin ksenobiyotikler ve diğer bileşiklerle konjugasyonunu katalize ederek antioksidan korumada etkilidir. GST, birkaç gen sınıfını (GSTA, GSTM, GSTP, GSTT, GSTZ, GSTS, GSTK, GSTO) kapsar. GSTM1 ve GSTT1, insanlarda genetik çeşitlilik göstermektedir [25]. Yang M ve ark., Çinli işçilerde GBİK gelişimi ile GSTM1 ve GSTT1 gen polimorfizmlerinin ilişkisini araştırmışlardır. Sonuçlar, GSTTI1 genindeki genetik polimorfizmin Çinli işçilerde GBİK gelişiminde önemli bir rol oynayabileceğini göstermiş ve GSTT1 null genotipine sahip bireylerin GBİK'ya daha duyarlı olabileceği ortaya konulmuştur [21].

Gürültüye atfedilebilen koklear epitel hasarı, endüstriyel işçilerde kalıcı işitme kaybının önemli bir nedenidir. Çalışmalar, gürültünün lokal serbest radikal salınımını indükleyerek koklear duyu epiteline zarar verebileceğini göstermiştir. Reaktif oksijen türleri manganez-süperoksit dismutaz (SOD2) ve antioksidan paraoksonazın (PON) düzenlenmesinde yer alan genler, kokleanın gürültüye duyarlılığını etkileyebilir. SOD enzimleri, süperoksit radikallerinin hidrojen peroksite dönüşümünü katalize eder. PON2 bir antioksidan enzim görevi görür. PON2 aşırı üretimi, hidrojen peroksit tarafından indüklenen hücrelerin oksidatif durumunu düşürme özelliğine sahiptir. Fortunato $G$ ve arkadaşları, uzun süreli yüksek gürültüye maruz kalan işçilerde GBİK duyarlılığının SOD2, PON1 ve PON2 polimorfizmleri ile ilişkili olup olmadığını araştırmıştır. SOD2 ve PON2 polimorfizmlerinin lokal doku antioksidan rolleri göz önüne alındığında GBİK'ya yatkınlık oluşturabileceğini ortaya koymuşlardır [15].

Katalaz geni (CAT) 11p13'te lokalizedir ve kodlama bölgesi 1581 bp'den oluşur. Konings A ve ark., oksidatif strese dahil olan genlerden biri olan CAT genindeki varyasyonların gürültü duyarlılığını etkileyip etkilemediğini araştırmışlar ve katalaz SNP'leri ile haplotiplere duyarlılık ve GBİK gelişimi arasında önemli ilişkiler bulmuşlardır. Bu sonuçlar, katalazın bir GBİK duyarlılık geni olduğunu ve gürültüye maruz kalma seviyeleri dikkate alındığında CAT polimorfizmlerinin etkisinin tespit edilebileceğini göstermektedir [18].

\subsection{Hsp70 genleri}

Isı şok proteinleri (HSP'ler), ekspresyonları fizyolojik stres, ototoksik ilaçlar, yüksek sıcaklık ve gürültü ile uyarılan fonksiyonel olarak ilişkili proteinlerin bir sınıfıdır. Yüksek oranda korunmuş ve en bol şaperon olan 1S1 şoku protein 70 (HSP70), çeşitli hücresel bölmelerde bulunur. HSP70 gen ailesi, HSP70-1, HSP70-2 ve HSP70-hom'dan oluşur. Birkaç çalışma, iç kulakta HSP70 üretiminin, sisplatin ve aminoglikozitlerin ototoksik etkilerine karşı koyarak saç hücrelerini koruduğunu göstermiştir [1]. Hücreleri oksidatif stresten koruyan bir grup proteini kodlayan HSP70 genleri söz konusudur. GBİK duyarlılığını etkilediği düşünülen diğer genler, iç kulak potasyum geri dönüşüm yolağı genlerini ve

54 | P a g e

www.iiste.org 
monojenik işitme kaybı genlerini içermektedir. Lei S ve arkadaşları, HSP70 gen polimorfizmleri ile GBİK duyarlılı̆̆ı arasındaki ilişkiyi kapsamlı ve sistematik olarak değerlendirmişlerdir. Meta analiz sonuçlarına göre, rs1043618, rs2075800 ve rs2763979 polimorfizmlerinin GBİK'ya duyarlılıkla ilişkili olmadığını, rs1061581 ve rs2227956 polimorfizmlerinin ise Kafkas erkeklerinde GBİK ile önemli ölçüde ilişkili olduğunu göstermiştir. Elde edilen bu veriler doğrultusunda GBİK'ya duyarlı popülasyonlar, genetik testlerle tanımlanabilir ve işitmelerini korumak için ilgili önlemler alınabilir [1].

\subsection{Monogenik işitme kaybı genleri}

Protocadherin 15 geni (PCDH15), kaderin süper ailesinin bir üyesidir. İntegral bir membran proteinini kodlar ve kalsiyuma bağımlı hücre-hücre yapışmasına aracılık eder. PCDH15, hücrelerin birbirine yapışmasına yardımcı olur ve normal retina ile koklear fonksiyonunun korunmasında önemli bir rol oynar. PCDH15, iç kulak hücrelerinde, gözdeki özel hücrelerde ve retina fotoreseptör hücrelerinde eksprese edilir. PCDH15'in retinadaki tam işlevi tam olarak belirlenmemiştir. PCDH15, harmonin, SANS veya whirlin tarafindan bağlanan Cadherin23, USH2A ve VLGR1 proteinleri ile etkileşime girer ve sinaptik zarları, büyük hücre dışı bölgelerinin homotipik veya heterotipik etkileşimleriyle yakından ilişkilendirir. PCDH15'in genetik varyasyonları ve mesleki gürültüye maruz kalma ile etkileşimleri, GBİK'ya genetik duyarlılık ile ilişkilidir ve gürültüye bağlı işitme kaybı riskini değiştirir [4]. Cadherin 23 (CDH23), hücre-hücre adezyonuna aracılık eden süper aile transmembran proteinlerinin bir üyesidir. CDH23, insan popülasyonunda işitme kaybının, gürültü kaynaklı işitme kaybına yatkınlıkla ilişkilendirilmesine neden olduğu bilinen ilk gendir. CDH23V homozigot mutantlarında, stereocilia demeti dağınıktır ve CDH23'ün crosslink stereocilia'nın hücre dışı filamentlerinden birinin bir bileşeni olabileceği öne sürülmüştür. MYO7A'nın harmonin ile etkileşime girdiği gösterilmiştir ki bu da CDH23 ile etkileşime girer (24).

Kas dışı ağır zincir II C (NMHCII-C) olarak da bilinen MYH14 geni, miyozin üyelerinden birini kodlar. MYH14'ün, kuvvet oluşturmak için ATP hidrolizi ile aktin filamentleri boyunca hücre bileşenlerinin yönlendirilmiş hareketinde önemli bir rol oynadığı belirtilir. MYH14 geninin periferik nöropati, miyopati, ses kısıklığ 1 ve işitme kaybıyla ilişkili olduğu rapor edilmiştir ve MYH14 proteini, Corti organı, spiral çıkıntı epiteli, stria vaskülaris ve koklear kanal gibi koklear dokularda yaygın olarak eksprese edilir. MYH14 gen mutasyonlarının sendromik olmayan/sendromik sensorinöral işitme kayb1 ile ilişskili olduğu belirtilmiştir. MYH14'teki mutasyonların otozomal dominant sendromik olmayan işitme kaybı-4A (DFNA4) ile sonuçlandığı bildirilmiştir [17].

\subsection{Potasyum geri dönüşüm yolağı genleri}

Voltaj kapılı $\mathrm{K}+(\mathrm{Kv})$ kanalları esas olarak, aksiyon potansiyelleri gibi membran boyunca voltajdaki değişikliklerin hızlı kanal aktivasyonu ve deaktivasyonu gerektirdiği uyarılabilir hücrelerde ifade edilir. Kv kanalları arasında, KCNQ1 kanalı, kardiyomiyositler gibi uyarılabilir hücrelerdeki rollerine ek olarak, KCNQ1'in epitel gibi uyarılmayan hücrelerde önemli fizyolojik roller oynaması bakımından diğer birçok Kv kanalından farklıdır [19]. Potasyum voltaj kapılı kanal alt ailesi q üye 4 (KCNQ4), iyon homeostazının korunmasında ve tüylü hücre zarı potansiyelinin düzenlenmesinde önemli roller oynayan voltaj kapılı bir potasyum kanalıdır. Genetik mutasyonlar nedeniyle KCNQ4 kanalının aktivitesinin azalması, zamanla ilerleyen, tipik olarak geç başlangıçlı, başlangıçta yüksek frekanslı bir kayıp olan nonsendromik işitme kaybından sorumludur. KCNQ4 varyantları ayrıca gürültüye bağlı işitme kaybı ve yaşa bağlı işitme kaybı ile ilişkilendirilmiştir. Bu nedenle, KCNQ4'ü aktive eden veya güçlendiren küçük bileşiklerin keşfi, işitme kaybının iyileştirici tedavisi için önemli bir stratejidir. Uygulanabilir spesifik KCNQ4 mutasyonu için ilacın yeniden kullanılması ve optimizasyonu, KCNQ4 aktivatörlerinin işitme kaybı tedavisinde klinik uygulaması için de novo ilaç keşfine kıyasla maliyeti düşürme ve süreyi kısaltma avantajlarıyla bir seçenek olabilir [23].

$\mathrm{K}+$, endolenf içine salgılanabilir, daha sonra apikal mekanik duyarlı $\mathrm{K}+$ kanalları yoluyla iç kulağın duyusal tüy hücrelerine girebilir. Ayrıca, K+'nın duyusal aktarım için son derece önemli bir yük taşıyıcısı olduğunu ve uygun geri dönüşümünün işitme için büyük önem taşıdığı tespit edilmiştir. K+ geri dönüşüm genleri, GBİK (KCNE1, KCNQ1, KCNQ4, KCNJ10, GJB1, GJB2 ve GJB4) ile ilişkili daha önceki çalışmalarda kanıtlandığı gibi, işitme süreci için çok önemlidir. Miao L ve ark., hem KCNE1 rs2070358 hem de KCNQ4 rs34287852'nin Polonya ve İsveç popülasyonlarında çalışıldığını ve GBIKK duyarlılığını etkilediğini bulmuşlardır. Pawelczyk ve ark., GJB2 rs3751385'in Polonya popülasyonunda GBİK ile önemli ölçüde ilişkili olduğunu bulmuşlardır; bu sonuçlar, Çin popülasyonundaki bir vaka-kontrol çalışmasında pozitif ilişkileri doğrulayarak, rs3751385'in GBİK'ya duyarlılık için bir biyobelirteç olabileceğini göstermiştir [13]. 


\section{Sonuç}

Mesleki gürültü, endüstriyel işçilerin sağlığı için en yaygın mesleki tehlikelerden biridir ve gürültüye bağlı işitme kaybı, dünya çapında yaşa bağlı işitme kaybının yanı sıra ikinci en sık görülen sensörinöral işitme bozukluğu türüdür [30]. Gürültüye bağlı işitme kaybı, hem genetik hem de çevresel faktörlerin etkileşiminden kaynaklanan bir tür çok faktörlü hastalık olduğu doğrulanmıştır[14]. GBİK’nın mekanizması çevresel faktörler olarak gürültü ile ilişkisi olduğu kesin olarak bilinmesine rağman, genetik rolleri üzerinde çalışmalar devam etmektedir. Muhtemel etyopatogenez, oksidatif stresin neden olduğu iç kulak hücresi apoptozunu veya nekrozunu veya sinyal iletimi sırasında üretilen metabolik ürünleri ve koklea yapılarına doğrudan mekanik hasarı içerebilir [3]. Bununla birlikte, çok sayıda popülasyon çalışması, kişilerin eşit gürültü yoğunluğu seviyesine maruz kalsalar bile çeşitli derecelerde GBİK riskine sahip olduklarını göstermiştir [9]. Hayvan deneyleri ayrıca genetik varyasyonların GBİK insidansına katkıda bulunduğunu kanıtlamaktadır [32]. Önceki çalışmalar, HSP70, EYA4, CDH23, GRHL2 ve DFNA5 genlerindeki tek nükleotid polimorfizminin (SNP'ler), gürültüye bağl1 işitme kaybına karşı insan genetik duyarlılığı ile ilişkili olduğunu ve mesleki gürültü ile etkileşim yoluyla gürültüye bağlı işitme kaybı riskini artırabileceğini veya azaltabileceğini bulmuştur [6]. Bulguların 1şı̆̆ı altında genetik yatkınlık ve çevresel faktörlerle etkileşimi, GBİK'nın ortaya çıkması ve gelişmesinde önemli bir rol oynayabilir.

Carlsson PI ve ark., insan koruyucu antioksidan sistemindeki genetik varyasyonun GBİK'ya yüksek veya düşük duyarlılıkla ilişkili olup olmadığını araştırmışlar ve gürültüye en duyarlı ve en dirençli işçilerde oksidatif stres yanıtında yer alan genlerden türetilen genetik polimorfizmleri analiz etmişlerdir. GSTM1 ve GSTT1 geni için delesyon polimorfizmi ve CAT, SOD, GPX, GSR ve GSTP1 genlerinden türetilen SNP bölgeleri değerlendirilmiş ve duyarlı ve dirençli gruplar arasında antioksidan enzimlerin genetik varyasyonunda GBİK'ya duyarlılık açısından anlamlı bir fark bulunmamıştır [5]. Konings A ve ark., gürültüye maruz kalan iki bağımsız popülasyonda katalazdaki değişiklikler ve GBİK duyarlılığı arasında birkaç ilişki bulmuşlardır. Genotipik varyasyonlar ile gürültüye maruz kalma seviyeleri ve bunların GBİK üzerindeki etkileri arasında önemli etkileşimler elde edilmiş ve çoğunlukla yüksek seviyeli gürültüye maruz kalma grubunda önemli ana etkilere yol açmıştır [18]. Sheng Li W ve arkadaşlar1, CDH23, GSTP1, GJB2, PMCA2, SOD2 ve CAT genlerindeki SNP'leri ve mesleki olarak gürültüye maruz kalan bir grup Çinli işçide GBİK gelişimini açıklayabilecek gen-gen etkileşimlerini analiz etmişlerdir. Reaktif oksijen türleri manganez-SOD2 ve CAT'nin düzenlenmesinde yer alan genlerin kokleanın gürültüye duyarlılığını etkileyebileceği, gürültünün serbest radikallerin salınımını indüklediği ve koklear duyu epiteline zarar verebileceği iyi bilinmektedir. Sheng Li W ve ark., GJB2 polimorfizmlerinin GBİK'y1 etkileşimli bir şekilde açıklayabileceğini öne sürmüşlerdir. GJB2 mutasyonları genellikle kalıtsal işitme kaybı olan bireyler için risk olarak kabul edilir [8].

Şiddetli gürültüye maruz kalma, 1S1 şoku proteinlerini indükleyebilir ve orta düzeyde gürültüye maruz kalmanın, gürültünün neden olduğu işitme hasarına karşı koruma sağladığı bildirilmiştir. GBİK ile hem yapısal hem de uyarılabilir hsp70 genlerinde herhangi bir genetik varyasyon ilişkisi olup olmadığı şu anda bilinmemektedir. Yang M ve arkadaşlarının çalışma sonuçları, GBİK grubu ile yaş, cinsiyet, sigara içme, patlayıcı gürültüye maruz kalma ve kümülatif gürültüye maruz kalma geçmişi, hastalık öyküsü düzeltmesi olan ve olmayan normal grup arasında hsp70-1, hsp70-2 ve hsp70-hom'un genotip ve allel dağılımlarında istatistiksel olarak anlamlı bir fark olmadığını göstermiştir. Mevcut veriler, hsp70 genlerindeki genetik varyasyonun GBİK'ya yatkınlığa katkıda bulunabileceğini düşündürmektedir. Hsp'ler, sayısız fiziksel ve fizyolojik stres tarafindan indüklenen filogenik olarak korunmuş proteinler, gürültü ve ototoksik ilaçlar tarafindan da indüklenebilir. Ayrıca, Hsp’ler, orta düzeyde travmatik olmayan ses seviyelerine yanıt olarak uyarıldığında, belirgin bir bireysel değişkenlik olmasına rağmen, kulağ1 yüksek gürültünün etkilerine dayanacak şekilde ayarlayabilir ve işitme kaybından koruyabilir [33].

GBİK, sensörinöral işitme kaybının en sık görülen ikinci şeklidir. Aynı gürültüye maruz kaldığında, bazı çalışanlar GBİK geliştirirken diğerleri geliştirmez, bu da GBİK'nin genetik faktörlerle ilişkili olabileceğini düşündürmektedir. Li Y ve arkadaşları, HSP70 genlerindeki (HSPA1A, HSPA1B ve HSPA1L) SNP'ler ile gürültüye maruz kalan Çinli işçilerde GBİK'ya duyarlılık arasındaki ilişkiyi araştırmışlardır. Elde edilen sonuçlar, HSP70 genlerinin rs2763979 lokusunun Çinli bireylerde GBİK'ya duyarlılık ile ilişkili olabileceğini ve diğer HSP70 genlerinin de GBİK için duyarlılık genleri olabileceğini, ancak sonuçların ek bağımsız örnek setlerinde daha fazla çoğaltılması gerektiğini göstermektedir [7]. MYH14, organel translokasyonu, hücre iskeletinin yeniden düzenlenmesi ve iyon kanalı geçişi gibi birçok hareketlilik sürecinde yer alır. Koklear duyu hücrelerinin epitelinde hücresel yeniden şekillenmede aktif bir role sahiptir. MYH14 geninin inhibisyonu, MYH14 gen mutasyonları taşıyan kişilerde işitme bozukluğunun fizyolojik mekanizması olabilen koklear kanalın uzamasında kusurlara yol açabilir. MYH14 genindeki mutasyonlar periferik nöropati, ses kısıklığı, miyopati ve

56 | $\mathrm{P}$ a g e

www.iiste.org 
işitme kaybına neden olabilir [17]. PCDH15, kalsiyuma bağımlı hücre-hücre yapışmasına aracılık eden bir proteini kodlayan kaderin süper ailesinin bir üyesidir. Normal retinal ve koklear fonksiyonun korunmasında önemli bir rol oynar. Bu gendeki mutasyonlar hem sendromik olmayan (DFNB23) hem de sendromik işitme kaybı (Usher sendromu tip 1F, USH1F) ile ilişkilendirilmiştir [34]. Van L ve ark., genetik değişkenliğin GBİK üzerindeki etkisini kapsamlı bir şekilde incelemişler ve KCNE1, KCNQ1 ve KCNQ4 genlerinin ve GBİK'nın varyantları arasındaki genetik ilişkileri sunarak bu genlerin GBİK duyarlılık genleri olabileceğini göstermiştir. KCNQ4'teki mutasyonlar, otozomal dominant tipte bir işitme kaybından sorumludur. KCNQ4, depolarizasyon üzerine yavaşça aktive olan ve esas olarak kokleanın dış tüy hücrelerinin (DTH'lar) bazal membranında ve vestibüler organın tip I tüy hücrelerinde eksprese edilen homomerik potasyum kanalları oluşturur. KCNQ4 kaybı, DTH'ların kronik potasyum aşırı yüklenmesine neden olarak yavaş dejenerasyonlarına neden olabilir [24]. Van Laer L ve ark., KCNE1, KCNQ1 ve KCNQ4 genlerinin varyantları ile GBİK arasındaki genetik ilişkileri sunmuşlar ve bu genlerin ilk GBİK duyarlılık genleri olabileceğini göstermişlerdir. Çin hamster yumurtalık hücrelerinde eksprese edildiğinde kanal özelliklerini değiştirdiği için KCNE1 p.D85N'yi olası nedensel SNP olarak belirlemişlerdir. GBİK gelişimine yol açan genetik risk faktörlerinin tanımlanması, maruz kalan işçilerin sağlı̆̆ üzerinde çok önemli bir etkisi olacak olan daha etkili önleme ve tıbbi tedavi yöntemlerine yol açabilir [29]. Genetik duyarlılık polimorfizmlerinin hastalık riskini belirlemede önemli bir etkisi olmakla birlikte, çalışma ortamlarında geniş ölçekli genetik taramalar, bir takım etik ve sosyal kaygılar sebebiyle sınırlıdır. Bu yüzden işyerlerinde büyük ölçekli genetik taramaların uygulanması şu anda tavsiye edilmemektedir [12].

Gürültüye bağlı işitme kaybı, gürültüye maruz kalma seviyeleri, gürültüye maruz kalma süresi, gürültü özellikleri, diğer faktörlerle etkileşim (yüksek sıcaklık, organik çözücüler, vb.), bireysel sağlıkla ilgili davranışlar (kişisel koruyucu önlemler, sigara içme, içme vb.), bireysel duyarlılık, bireysel sağlık durumu (hipertansiyon, hiperlipemi vb.) dahil olmak üzere birçok faktörle ilişkilidir. Genetik faktörler ve gen-çevre etkileşimleri de GBİK gelişiminde önemli roller oynayabilmektedir. Araştırmacılar, uzun süreli hayvan deneylerinde ve popülasyon çalışmalarında, aynı gürültüye maruz kalma altında bile, farklı deney hayvanları ve popülasyonları arasında işitme eşiği yer değiştirme derecesinin değiştiğini bulmuşlardır. Bu, GBİK olan bireylerin farklı duyarlılıklara sahip olduğunu göstermektedir. Ayrıca, bazı araştırmacılar koklear saç hücresi hasarının ve ölümünün bireylerde GBİK'ya neden olabileceğini bildirmiştir.

Mevcut metabolik hasar teorileri, yüksek sese maruz kalmayla tetiklenen kokleada aşırı reaktif oksijen türleri (ROS) ve reaktif nitrojen türleri (RNS) oluşumunu ve ardından apoptoz ile kaspaz aracılı hücre ölümünü içeren oksidatif strese odaklanır. Gürültüye maruz kaldıktan hemen sonra koklear dokuda ROS tespit edildiği ve Corti organının bazal ucundan apikal dönüşe yayılarak günler sonra dahi devam ettiği görülmüştür. $\mathrm{Bu}$ uzun süreli oksidatif stresin gecikmiş ve devam eden koklear yaralanmayı indüklediği öne sürülmektedir. Oksidatif stres ve sinaptik eksitotoksisite, morfolojik patolojilerin ana mekanizmalarıdır. Bununla birlikte, benzer seviyelerde gürültüye maruz kalma altında, işçiler farklı yoğunlukta işitme hasarına maruz kalabilirler. Farklılıklar, gürültüye maruz kalınan ortamlarda GBİK insidansında genetik duyarlılığın önemli bir rol oynadığını göstermektedir. Ayrıca, gürültünün, daha büyük bir apikal potasyum akışına yol açarak bu süreci hızlandırabileceği varsayılmaktadır. Potasyum geri dönüşüm yolağı genlerindeki genetik varyasyonların, GBİK'ya karşı bireysel duyarlılığın belirlenmesinde rol oynadığı söylenebilir. GBİK'ya yol açan moleküler mekanizmaların aydınlatılması için daha fazla genetik ve fonksiyonel analiz gereklidir. Günümüzde, yüksek verimli genotipleme yöntemlerinin geliştirilmesi, şüphesiz yeni GBİK duyarlılık genlerinin tanımlanmasına yol açacak olan tek bir dizide yüzlerce ve binlerce tek nükleotid polimorfizminin (SNP) saptanmasına olanak tanır. Ek olarak, GBİK gibi karmaşık bir bozukluğun tam profilini elde etmek için sigara içme, yüksek kan basıncı veya kolesterol seviyeleri gibi diğer potansiyel çevresel ve bireysel risk faktörleri analiz dahil edilmelidir.

\section{References}

[1] Abreu-Silva RS, Rincon D, Horimoto AR, Sguillar AP, Ricardo LA, Kimura L, Batissoco AC, De Mello Auricchio MB, Otto PA, Mingroni-Netto RC. (2011), "The search of a genetic basis for noise-induced hearing loss (NIHL)". Ann Hum Biol 38(2), 210-8.

[2] Barro-Soriaa R, Ramentola R, Liina SI, Pereza ME, Kassb RS, Larsson HP.(2017), "KCNE1 and KCNE3 modulate KCNQ1 channels by affecting different gating transitions". Proc Natl Acad Sci USA 114(35), E7367-E7376.

57 I $P$ a g e

www.iiste.org 
[3] Carlsson PI, Laer LV, Borg E, Bondeson ML, Thys M, Fransen E, Van Camp G.(2005), "The influence of genetic variation in oxidative stress genes on human noise susceptibility". Hear Res 202(1-2), 87-96.

[4] Chang NC, Ho CK, Lin HY, Yu ML, Chien CY, Ho KY. (2011), “Association of polymorphisms of heat shock protein 70 with susceptibility to noise-induced hearing loss in the Taiwanese population”. Audiology \& neuro-otology 16(3), 168-74.

[5] Clifford RE, Hertzano R, Ohlemiller KK.(2019), "Untangling the genomics of noise-induced hearing loss and tinnitus: Contributions of Mus musculus and Homo sapiens". J Acoust Soc Am $146(5), 4007$.

[6] Davis RR, Newlander JK, Ling X, Cortopassi GA, Krieg EF, Erway LC. (2001), "Genetic basis for susceptibility to noise-induced hearing loss in mice". Hear Res 155(1-2), 82-90.

[7] Fortunato G, Marciano E, Zarrilli F, Mazzaccara C, Intrieri M, Calcagno G, Vitale DF, La Manna P, Saulino C, Marcelli V, Sacchetti L.(2004), "Paraoxonase and superoxide dismutase gene polymorphisms and noise-induced hearing loss". Clin Chem 50(11), 2012-8.

[8] Han Y, Hong L, Zhong C, Chen Y, Wang Y, Mao X, Zhao D, Qiu J. (2012), "Identification of new altered genes in rat cochleae with noise-induced hearing loss". Gene 499(2), 318-22.

[9] Henderson D, Bielefeld EC, Harris KC, Hu BH. (2006), “The role of oxidative stress in noiseinduced hearing loss". Ear Hear 27(1), 1-19.

[10] Holme RH, Steel KP. (2004), "Progressive hearing loss and increased susceptibility to noiseinduced hearing loss in mice carrying a Cdh23 but not a Myo7a mutation". J Assoc Res Otolaryngol 5(1), 66-79.

[11] Hu L, Deng JH. (2014), "Progress in the association studies on susceptibility gene SNP for NIHL in human population". Occup and Health 30(18), 2664-2669.

[12] Konings A, Van Laer L, Pawelczyk M, Carlsson PI, Bondeson ML, Rajkowska E, Dudarewicz A, Vandevelde A, Fransen E, Huyghe J, Borg E, Sliwinska-Kowalska M, Van Camp G. (2007), "Association between variations in CAT and noise-induced hearing loss in two independent noise-exposed populations". Hum Mol Genet 16(15), 1872-83.

[13] Konings A, Laer LV, Smagur AW, Rajkowska E, Pawelczyk M, Carlsson PI, Bondeson ML, Dudarewicz A, Vandevelde A, Fransen E, Huyghe J, Borg E, Sliwinska-Kowalska M, Van Camp G. (2009), "Candidate Gene Association Study for Noise-induced Hearing Loss in Two Independent Noise-exposed Populations". Annals of Human Genetics 73(2), 215-224.

[14] Konings A, Van Laer L, Van Camp G. (2009), “Genetic studies on noise-induced hearing loss:a review". Ear Hear 30(2), 151-9.

[15] Kowalska MS, Pawelczyk M. (2013), "Contribution of genetic factors to noise-induced hearing loss: a human studies review”. Mutat Res 752(1), 61-65.

[16] Lei S, Huang L, Liu Y, Xu L, Wang D, Yang L. (2017), “Association between polymorphisms of heat-shock protein 70 genes and noise-induced hearing loss: A meta-analysis". PLoS One 12(11), e0188539.

[17] Li Wang S, Gang Yu L, Liu RP, Zhu WZ, Gao WM, Xue LP, Jiang X, Zhang YH, Yi D, Chen D, Zhang YH. (2014), "Gene-gene interaction of GJB2, SOD2, and CAT on occupational noiseinduced hearing loss in Chinese Han population”. Biomed Environ Sci 27(12), 965-8. 
[18] Li YH, Yang Y, Yan YT, Xu LW, Ma HY, Shao YX, Cao CY, Wu X, Qi MJ, Wu YY, Chen R, Hong Y, Tan XH, Yang L. (2018), "Analysis of serum microRNA expression in male workers with occupational noise-induced hearing loss”. Braz J Med Biol Res 51(3), e6426.

[19] Li Y, Yu S, Gu G, Chen G, Zheng Y, Jiao J, Zhou W, Wu H, Zhang Z, Zhang H, He L, Yang Q, Xu X. (2017), "Polymorphisms of heat shock protein 70 genes (HSPA1A, HSPA1B and HSPA1L) and susceptibility of noise-induced hearing loss in a Chinese population: A casecontrol study". PLoS One 12(2), e0171722.

[20] Miao L, Ji J, Wan L, Zhang J, Yin L, Pu Y. (2019), “An overview of research trends and genetic polymorphisms for noise-induced hearing loss from 2009 to 2018”. Environ Sci Pollut Res Int 26(34), 34754-34774.

[21] Mirza R, Kirchner DB, Dobie RA, Crawford J. (2018), “Occupational Noise-Induced Hearing Loss". J Occup Environ Med 60(9), e498-e501.

[22] Ohlemiller KK, Wright JS, Dugan LL. (1999), "Early elevation of cochlear reactive oxygen species following noise exposure". Audiol Neurootol 4(5), 229-236.

[23] Öztan G, İşsever H. (2020), "Molecular Mechanisms Of Genetic Polymorphisms Related To Occupational Diseases”. J Ist Faculty Med 83(2), 152-61.

[24] Pawelczyk M, Van Laer L, Fransen E, Rajkowska E, Konings A, Carlsson PI, Borg E, Van Camp G, Sliwinska-Kowalska M. (2009), “Analysis of Gene Polymorphisms Associated with $\mathrm{K}+$ Ion Circulation in the Inner Ear of Patients Susceptible and Resistant to Noise-induced Hearing Loss". Annals of Human Genetics 73,411-42.

[25] Reddy ST, Wadleigh DJ, Grijalva V, Ng C, Hama S, Gangopadhyay A, et al. (2001), "Human paraoxonase-3 is an HDL-associated enzyme with biological activity similar to paraoxonase-1 protein but is not regulated by oxidized lipids". Arterioscler Thromb Vasc Biol 21(4), 542-547.

[26] Rim JH, Choi JY, Jung J, Yung Gee H. (2021), “Activation of KCNQ4 as a Therapeutic Strategy to Treat Hearing Loss". Int J Mol Sci 22(5), 2510.

[27] Tessier-Sherman B, Galusha D, Cantley LF, Cullen MR, Rabinowitz PM, Neitzel RL. (2017), "Occupational noise exposure and risk of hypertension in an industrial workforce". Am J Ind Med 60(12), 1031-1038.

[28] The Institute for Health Metrics and Evaluation. Global Health Data Exchange, (2017), [Online] Available: http://ghdx.healthdata.org/gbd-results-tool (June 13, 2020).

[29] Van Laer L, Carlsson PI, Ottschytsch N, Bondeson ML, Konings A, Vandevelde A, Dieltjens N, Fransen E, Snyders D, Borg E, Raes A, Van Camp G.(2006), "The Contribution of Genes Involved in Potassium- Recycling in the Inner Ear to Noise-Induced Hearing Loss". Hum Mutat 27(8), 786-95.

[30] Wang B, Han L, Dai S, Li X, Cai W, Yang D, et al. (2018), "Hearing Loss Characteristics of Workers with Hypertension Exposed to Occupational Noise: A Cross-Sectional Study of 270,033 Participants". Biomed Res Int (9), 1-6.

[31] Wang M, Zhou Y, Zhang F, Fan Z, Bai X, Wang H. (2020), “A novel MYH14 mutation in a Chinese family with autosomal dominant nonsyndromic hearing loss". BMC Medical Genetics 21,154 .

[32] White CH, Ohmen JD, Sheth S, Zebboudj AF, McHugh RK, Hoffman LF, et al. (2009), "Genome-wide screening for genetic loci associated with noise-induced hearing loss". Mammalian genome: official journal of the International Mammalian Genome Society 20(4), 207-13. 
[33] Yang M, Tan H, Zheng J, Jiang CZ.(2005), "Relationship between GSTM1 and GSTT1 gene polymorphisms and noise induced hearing loss in Chinese workers". Wei Sheng Yan Jiu 34(6), 647-9.

[34] Yang M, Tan H, Yang Q, Wang F, Yao H, Wei Q, Tanguay RM, Wu T. (2006), “Association of hsp70 polymorphisms with risk of noise-induced hearing loss in Chinese automobile workers". Cell Stress Chaperones 11(3), 233-239.

[35] Zhang X, Liu Y, Zhang L, Yang Z, Shao Y, Jiang C, Wang Q, Fang X, Xu Y, Wang H, Zhang S, Zhu Y.(2014), "Genetic variations in protocadherin 15 and their interactions with noise exposure associated with noise-induced hearing loss in Chinese population”. Environ Res 135, 247-52. 